\title{
Hak Atas Informasi, Edukasi Dan Pelayanan Kesehatan Terhadap Masyarakat Adat Di Maluku Selama Pandemi Covid-
}

\author{
Arman Anwar ${ }^{1 *}$, Richard Marsilio Waas ${ }^{2}$ \\ 1, 2, Fakultas Hukum Universitas Pattimura, Ambon, Indonesia \\ *E-mail: arman.mances.1970@gmail.com
}

Dikirim: 21/12/2021

\begin{tabular}{l}
\hline Info Artikel \\
\hline Keywords: \\
Pandemic; \\
Protection; Right; \\
Indigenous Peoples; \\
Public Policy. \\
\\
Kebijakan Publik. \\
Pandemik; \\
Masyarakat Adat; \\
Kata Kunci:
\end{tabular}

Direvisi: 20/05/2021

Dipublikasi: 04/06/2021

\section{Abstract}

The main objective of this research is to determine the fulfillment of the right to information, education and health services to indigenous peoples carried out by the Maluku Provincial Government and the relationship patterns that need to be built through the Maluku Provincial Government's public policies towards indigenous peoples so that dynamic interactions can be established in an effort to accelerate the spread of the virus. Covid 19 at the local level. The research was conducted using the Social Legal Research method. Approach the problem using a statutory approach, and concepts. The results of this study found that the Maluku Provincial Government has carried out its responsibilities in fulfilling the right to information, education and health services to indigenous peoples, but it is still not optimal. Likewise, a public policy framework that favors the interests of indigenous peoples as a form of protection for the vulnerability of indigenous peoples from the dangers of the spread of the Covid-19 virus is also not optimal. The Maluku Provincial Government needs to formulate a formulation of a public policy framework that is oriented towards the goal of fulfilling the basic rights of indigenous peoples during the Covid-19 pandemic. The vulnerability of indigenous peoples needs to be protected with the political will of the Maluku Provincial government through budget politics, preparation of human and material resources and infrastructure that supports performance achievement in fulfilling the right to information, education and health services to indigenous peoples at the local level. 
DOI:

10.47268/sasi.v27i2.454

informasi, edukasi dan pelayanan kesehatan kepada masyarakat adat, namun relatif masih belum maksimal. Demikian pula kerangka kerja kebijakan publik yang lebih berpihak kepada kepentingan masyarakat adat sebagai bentuk tindakan perlindungan atas kerentanan masyarakat adat dari bahaya penyebaran virus covid-19 juga belum optimal. Pemerintah Provinsi Maluku perlu merumuskan formulasi kerangka kerja kebijakan publik yang berorientasi kepada tujuan pemenuhan hak-hak dasar masyarakat adat selama masa pandemic covid-19. Kerentanan masyarakat adat perlu dilindungi dengan "political will" pemerintah Provinsi Maluku melalui politik anggaran, penyiapan sumber daya manusia dan material serta infrastruktur yang mendukung pencapaian kinerja untuk pemenuhan hak atas informasi, edukasi dan pelayanan kesehatan kepada masyarakat adat di tingkat lokal.

\section{A. PENDAHULUAN}

Penelitian ini lebih difokuskan pada hak-hak masyarakat khususnya masyarakat adat di Maluku atas infomasi, edukasi dan pelayanan kesehatan selama masa pandemi Covid 19. Karena mengingat yang akan diteliti adalah pengaturan tentang hak-hak yang mendasar bagi masyarakat hukum adat dan telah dijamin dalam Undang-Undang Dasar NRI 1945. Demikian pula dalam berbagai peraturan perundang-undangan seperti Undang-Undang Nomor 36 Tahun 2009 Tentang Kesehatan, dan Undang-Undang No. 14 Tahun 2008 Tentang Keterbukaan Informasi Publik maka isu hukum yang akan menjadi vocal point dalam penelitian ini adalah tentang apakah pemenuhan dan perlindungan hak atas informasi, edukasi dan pelayanan kesehatan pada masyarakat adat selama pandemi Covid-19 telah dilakukan oleh pemerintah daerah Maluku.

Dasar pemikiran penelitian ini berangkat dari pengamatan di lapangan bahwa dengan merebaknya pandemik Covid-19 secara global. Pada 2020 tercatat 90.308 orang telah terinfeksi. ${ }^{1}$ Virus ini sangat berbahaya karena sifatnya yang sangat mudah menular. ${ }^{2}$ Oleh karena itu, WHO mengumumkan status Public Health Emergency of International Concern (PHEIC) karena virus ini eskalasinya tinggi dan telah menginfeksi banyak negara. ${ }^{3}$ Sehingga telah mengkhawatirkan masyarakat dunia internasional, termasuk masyarakat dan pemerintah Indonesia. Tindakan berbagai negara begitu sangat beragam seperti ada yang mengambil Tindakan ekstrim dengan melakukan lockdown suatu daerah tertentu, bahkan ada yang meliputi satu wilayah negara.

Persoalan pandemic virus Covid-19 tidaklah dapat dipandang remeh. Keunggulan virus berbahaya ini adalah memiliki daya tahan selama 10 menit sehingga mampu hidup di luar inang. ${ }^{4}$ Menurut Jaringan Masyarakat Sipil untuk Indonesia Bergerak bahwa tanggapan pemerintah Indonesia sangat lambat dalam menyiapkan sarana dan prasana kesehatan. Demikianpun kinerja birokrasinya yang sentralistik sehingga kebijakannya kurang transparan, dan komunikasi publiknya juga gagal. Akibatnya lambat dalam mendeteksi Covid-19. Kelemahan lainnya adalah karena minimnya peran pemerintah daerah, dan kurang perdulinya swasta, dan masyarakat dalam merespon hal itu. Semuanya ini telah menjadi kekhwatiran bagi

1 Yuliana, Y. (2020). Corona virus diseases (Covid-19): Sebuah tinjauan literatur. Wellness And Healthy Magazine, 2(1), 187-192, h. 192

2 Wu, Y. C., Chen, C. S., \& Chan, Y. J. (2020). The outbreak of COVID-19: an overview. Journal of the Chinese medical association, 83(3), 217-220, h. 217

3 Wahidah, I., Athallah, R., Hartono, N. F. S., Rafqie, M. C. A., \& Septiadi, M. A. (2020). Pandemik COVID-19: Analisis Perencanaan Pemerintah dan Masyarakat dalam Berbagai Upaya Pencegahan. Jurnal Manajemen dan Organisasi, 11(3), 179-188, h. 181

4 Zahrotunnimah, Z. (2020). Langkah taktis pemerintah daerah dalam pencegahan penyebaran virus Corona Covid-19 di Indonesia. SALAM: Jurnal Sosial Dan Budaya Syar-I, 7(3), 247-260, h. 247 
masyarakat Indonesia maupun dunia. Padahal upaya pemcegahannya mestinya menjadi tanggung jawab bersama pemerintah dengan seluruh kompenen masyarakat. ${ }^{5}$

Hal ini jangan sampai terjadi pada masyarakat hukum adat di Maluku yang berciri sebagai Propinsi Kepulauan sebagai ciri kewilayahan dengan sebutan seribu pulaunya. Aholiab Watloly mengatakan bahwa "Provinsi seribu pulau", bermakna filosofis bahwa masyarakat Maluku memiliki jati diri sebagai masyarakat kepulauan. Meskipun saling berjauhan, namun mereka secara lahiriah dan batiniah memiliki kehidupan yang otonom dan multi tipikal. Kondisi tersebut, membuat mereka secara hakiki dan mendasar mempunyai konsep tentang jati diri (true self) yang penuh dengan pranata nilai (value system), dan sikap hidup yang kebijaksanaan (local wisdom), dalam sebuah tatanan yang sesuai dengan kehidupan alamiah mereka. ${ }^{6}$

Pemerintah Maluku telah menerapkan kebijakan membatasi aktivitas sosial masyarakat degan skala regional (PSBR) dan pemerintah Kota Ambon sebelumnya juga telah menerapkan pembatasan kegiatan masyarakat (PKM) dan kemudian dilajutkan dengan menerapkan kebijakan dengan persetujuan pemerintah pusat yaitu menetapkan Kota Ambon sebagai Kota yang menerapkan kebijakan pembatasan sosial berskala besar. Namun masih terjadi pelanggaran. $^{7}$

Terjadinya pelanggaran ketentuan PSBB menunjukan bahwa masyarakat Kota Ambon yang mayoritas adalah masyarakat adat di Ambon belum teredukasi secara baik. Hal ini terjadi karena akses masyarakat adat atas informasi, edukasi dan pelayanan kesehatan belum maksimal. Beberapa contoh gejolak sosial yang terjadi di masyarakat adat sebagai reaksi atas kebijakan Pemerintah Kota Ambon dimaksud adalah seperti penolakan negeri-negeri adat di jazirah Leihitu atas Perwali Kota Ambon No 16 Tahun 2020 mengenai upaya membatasi aktivitas masyarakat, baik pembatasan aktivitas orang, maupun pembatasan di sektor transportasi, dan perekonomian. Bagi masyarakat adat di jazirah Leihitu menganggap bahwa peraturan tersebut telah mempersulit akses warga masyarakat adat Jazirah Leihitu di utara dan timur Pulau Ambon untuk masuk ke Kota Ambon. ${ }^{8}$ Reaksi penolakan atas kebijakan dan peraturan Pemerintah Kota Ambon juga dilakukan oleh masyarakat adat dengan melakukan penolakan terhadap pemakan jenazah Covid 19 di tempat pemakaman umum (TPU) Air Besar Kecamatan Sirimau Kota Ambon. Penolakan yang sama juga dilakukan oleh warga Dusun Taeno atas pemakaman jenazah Covid 19 di Pemakan umum (TPU) Jemaat Dusun Taeno Negeri Rumah Tiga. ${ }^{9}$ Sementara itu, di Negeri Adat Batu Merah juga terjadi aksi pencegatan mobil ambulance dan pengambilan paksa jenazah Covid 19. Jenazah tersebut adalah Mantan Raja dari Negeri adat di Kabupaten Maluku Tengah yang akan dimakamkan tanpa protokol kesehatan. ${ }^{10}$ Semua kasus ini menjadikan tolak ukur untuk mengetahui bahwa pemenuhan pemerintah daerah dalam memberikan hak atas informasi, edukasi dan pelayanan kesehatan kepada warga masyarakat adat belumlah maksimal.

5 Elfi Quyumi, E., Alimansur, M. (2020). Upaya Pencegahan Dengan Kepatuhan Dalam Pencegahan Penularan Covid-19 Pada Relawan Covid. Journal of Public Health Research and Community Health Development (JPH RECODE) 4(1), 81-87. DOI: http://dx.doi.org/10.20473/jphrecode.v4i1.21792, h. 82

6 Watloly, A. (2007). Filosofi Masyarakat Kepulauan, Disampaikan dalam Orasi Ilmiah pada Dies Natalis Universitas Pattimurta ke 44.

7 Herin, F. P. (2020). Pelanggaran Warnai Hari Pertama PSBB, Pemkot Ambon Siapkan Penindakan, https://www.kompas.id/baca/nusantara/2020/06/22/pelanggaran-warnai-hari-pertama-psbb-pemkot-ambonsiapkan-penindakan/.

8 Redaksiadmin. (2020). Gubernur Minta Warga Leihitu-Salahutu Bisa Masuk Kota. https://ameks.id/gubernur-minta-warga/.

9 Tribunnews.com. (2020). Sempat Ditolak Warga, Pemakaman Jenazah Pasien Positif Covid-19 di Ambon Penuh Isak Tangis Keluarga. https:/www.tribunnews.com/corona/2020/05/04/sempat-ditolak-warga-pemakamanjenazah-pasien-positif-covid-19-di-ambon-penuh-isak-tangis-keluarga

10 Satumaluku.id. (2020). Warga Hadang Ambulance dan Turunkan Paksa Jenazah Covid-19 di Tanjakan Batumerah Ambo. https://www.satumaluku.id/2020/06/26/warga-di-ambon-hadang-ambulance-turunkan-paksajenazah-covid-kasus-577-di-maluku/

$$
\text { 151|S A S Vol. } 27 \text { No.2, April - Juni } 2021
$$


Persoalan diatas menimbulkan isu hukum yang menarik untuk diteliti apalagi mengingat belum ada penelitian tentang hal ini di Indonesia. Penelitian di Indonesia masih secara umum membahas tentang masyarakat adat tanpa ada kaitannya dengan pandemic Covid 19. Para peneliti seperti Amrina Rosyada dkk, hanya meneliti tentang perlindungan kesatuan masyarakat hukum adat dalam mewujudkan keadilan sosial berdasarkan UUD NRI 1945. ${ }^{11}$ Penelitian terbaru di tahun 2020 juga belum membahas tentang perlindungan HAM masyarakat adat di masa pandemic, seperti penelitian yang dilakukan oleh Buana, D. R. Penelitiannya tentang perilaku masyarakat Indonesia selama pandemi Covid-19 dan cara-cara melindungi kesejahteraan Jiwa, namun tidak membahas sama sekali tentang kondisi masyarakat adat ditengah pandemic Covid 19. ${ }^{12}$ Demikian juga yang ditulis oleh peneliti N. Mona. tentang jaringan sosial dalam konsep isolasi untuk mengurangi efek contagious di Indonesia. ${ }^{13}$ Sementara, Riyanti Djalante dkk dalam penelitian mereka berjudul Review and analysis of current responses to COVID-19 in Indonesia selama periode dari Januari sampai Maret 2020, hanya mengkaji salah satu kelompok masyarakat yaitu kelompok Religious culture and tradition: source of strength or vulnerability. ${ }^{14}$ Demikianpun penelitian yang dilakukan Zahrotunnimah, dengan tema kebijakan Pemerintah Daerah berupa langkah taktis dalam upaya pemberantasan Covid-19 di Indonesia, hanya membahas tentang langkah-langkah taktis yang dilakukan oleh beberapa pemerintah daerah di Indonesia dalam melakukan penanggulangan virus covid-19 tanpa menjelaskan bagaimana langkah-langkah taktis tersebut diimplementasikan kepada masyarakat adat secara khusus. Bahkan Lembaga nongovernment organisation yang memiliki kompetensi dalam bidang masyarakat adat seperti Alians Masyarakat Adat Nusantara (AMAN) juga baru hanya sebatas mengeluarkan Instruksi tentang Pedoman Merespon Perkembangan Penyebaran COVID19. Oleh karena itu, maka penelitian ini sangat urgen untuk dilakukan.

\section{B. METODE PENELITIAN}

Metode penelitian menggunakan metode Social Legal Research, penelitian ini menurut Peter Mahmud Marzuki yaitu penelitian tentang hukum namun menjadikan hukum hanya sebagai gejala sosial, dimana perilaku individu atau masyarakat, lebih difokuskan dalam hubungannya dengan hukum. ${ }^{15}$ Pendekatan Penelitian menggunakan 3 pendekatan yaitu pertama, pendekatan perundang- undangan (statue approach) menggunakan UU No. 25 Tahun 2009 tentang Pelayanan Publik, UU No. 24 Tahun 2007 Tentang Penanggulangan Bencana dan UU No. 39 Tahun 1999 tentang Hak Asasi Manusia. Kedua, pendekatan konseptual (conceptual approach) menggunakan pendekatan konsep partisipasi, transparansi, akuntabiltas dan hak-hak konstitusi masyarakat adat sebagai warga Negara. Adapaun sumber hukumnya adalah bahan hukum primer, sekunder dan tersier. Prosedur pengumpulan dan analisis bahan hukum dilakukan mengikuti langkah-langkah yang disingkat dengan "IRAC" yaitu memilih masalah (issues), setelah itu menentukan peraturan hukum yang relevan (rule of law), kemudian melakukan analisis tentang fakta-fakta dari segi hukum (analysing the facts), berakhir dengan menetapkan kesimpulan (conclusion). ${ }^{16}$

11 Rosyada, A., Warassih, E., \& Herawati, R. (2018). Perlindungan Konstitusional terhadap Kesatuan Masyarakat Hukum Adat dalam Mewujudkan Keadilan Sosial. Kanun Jurnal Ilmu Hukum, 20(1), 1-22. DOI: https://doi.org/10.24815/kanun.v20i1.10021.

${ }_{12}$ Mona, N. (2020). Konsep isolasi dalam jaringan sosial untuk meminimalisasi efek contagious (kasus penyebaran virus corona di Indonesia). Jurnal Sosial Humaniora Terapan,2(2), 117-125. DOI: https://doi.org/10.7454/jsht.v2i2.86

13 Ibid.

14 Djalante, Riyanti, et al. (2020). Review and analysis of current responses to COVID-19 in Indonesia: Period of January to March 2020. Progress in Disaster Science, 6(4), 1-9. DOI: https://doi.org/10.1016/j.pdisas.2020.100091, h. 6

15 Marzuki, P. M. (2017). Penelitian Hukum. Edisi Revisi, Jakarta: Kencana, h. 87-93.

16 Hutchinson, T. (2006). Researching and writing in law. Pyrmont-NSW-Sydney: Thomas Lawbook Co, h. 32

$$
\text { 152|S ASI Vol. } 27 \text { No.2, April - Juni } 2021
$$




\section{PEMBAHASAN}

\section{Pemenuhan Hak Atas Informasi, Edukasi Dan Pelayanan Kesehatan Kepada Masyarakat Adat Oleh Pemerintah Provinsi Maluku}

Undang-Undang Dasar NRI 1945 menetapkan bahwa setiap orang berhak untuk berkomunikasi dan memperoleh informasi untuk mengembangkan pribadi dan lingkungan sosialnya, serta berhak untuk mencari, memperoleh, memiliki, menyimpan, mengolah, dan menyampaikan informasi dengan menggunakan segala jenis saluran yang tersedia (Pasal 28F). Atas dasar tersebut maka sesuai asas maximum access limited exemption yaitu bahwa pada prinsipnya seluruh informasi yang ada dibadan publik adalah harus terbuka dan mudah untuk diakses kecuali informasi yang dikecualikan (pengecualian itupun harus diatur secara ketat dan terbatas). Dengan demikian maka konstitusi memberikan jaminan pengakuan atas informasi merupakan hak asasi manusia.

Pasal 2 Undang-Undang Nomor 14 Tahun 2008 menegaskan bahwa terhadap semua informasi public ini harus dapat diperoleh secara cepat dan tepat waktu oleh setiap Pemohon. Hal ini bertujuan agar setiap setiap orang dapat dengan mudah mengetahui rencana pembuatan kebijakan atau program terkait kebijakan publik, sehingga dapat aktif dalam proses pengambilan keputusan, (Pasal 3).

Dalam rangka memenuhi kewajiban dimaksud maka pemerintah Provinsi Maluku telah melakukan berbagai cara dan bentuk penyebarluasan informasi tentang penanganan Covid 19 kepada masyarakat di Maluku. Ketua Komisi Penyiaran Indonesia Daerah Maluku (juga menjadi Juru bicara Gugus Tugas Percepatan Penanggulangan Covid 19 Provinsi Maluku) menjelaskan bahwa sesuai hasil penelitian Komisi Penyiaran Indonesia Daerah Maluku bahwa $100 \%$ masyarakat mengetahui informasi pesan pemerintah terkait dengan covid, upaya pencegahan dan sebagainya. Dan hal itu juga terpantau dari kami. SOP KIPD bahwa setiap 1 jam ada informasi tentang Covid tapi ternyata bukan hanya setiap setengah jam saja bahkan setiap 6 menit, 4 menit atau 3 menit ada running text, ada informasi. Jadi informasi itu sudah ada dan masyarakat sudah tahu.

Menangkapi hal tersebut maka Otis Kapitan (warga masyarakat yang berada di Negeri Huku Kecil, Kecamatan Elpaputih Kabupaten Seram Bagian Barat) menyampaikan konfrimasi bahwa masyarakat yang ada di Negeri terpencil di Kecamatan Elpaputih belum pernah menerima sosialisasi dari pemerintah terkait dengan Kesehatan dan Bantuan Sosial (BANSOS) dan Batuan Langsung Tunai (BLT). Demikian pula yang disampaikan oleh Poly (penduduk di Rumah Tiga) bahwa tidak ada informasi yang disampaikan oleh juru bicara Pemerintah Provinsi Maluku, selama ini yang memberikan informasi hanyalah dari Juru Bicara Pemerintah Pusat.

Dalam hal hak atas edukasi, sangat berkaitan erat dengan informasi, karena informasi adalah cara masyarakat adat diedukasi. Menurut Angki Nikijuluw (Humas Majelis Latupatti Maluku) bahwa Komunikasi publik Pemerintah Provinsi Maluku terlalu monoton karena yang ditampilkan hanya angka-angka statistik, seperti yang dirilis dalam website Gugus Tugas Covid 19 Provinsi Maluku. Sementara tidak semua masyarakat adat mampu memahami statistik. Demikianpun tentang edukasi kepada masyarakat adat tentang bahaya virus Covid 19 bagi Kesehatan juga belum tersosialisasikan dengan baik. Di dalam Gugus Tugas menurut beliau tidak ada keterwakilan Majelis Latupatti Maluku sebagai representasi masyarakat adat. Majelis Latupatti juga belum pernah dilibatkan dalam program pemerintah daerah dalam rangka untuk melakukan upaya perlindungan masyarakat adat dari bahaya penyebaran virus Covid 19. Oleh karena itu, menurut beliau Pemerintah Provinsi Maluku belum maksimal memutuskan mata rantai penyebaran covid 19 ke masyarakat adat.

Menyadari akan hal ini, Ketua Komisi Penyiaran Indonesia Daerah Maluku mengatakan bahwa semua berita yang buruk adalah milik Gugus Tugas (Gustu) tapi semua berita yang baik 
adalah milik masyarakat jadi sebaik apapun pemerintah bekerja tetap ada celah yang dikritisi karena tingkat kepuasan setiap manusia itu berbeda-beda, tergantung latar belakang dan faktor ekternal, intenal yang mempengaruhi. Komunikasi publik buruk, awalnya mungkin betul, kita bisa melihat pemerintah pusat juru bicaranya sampai dua yaitu dokter Ahmad sebagai juru bicara Gugus Tugas dan dokter Raisya sebagai juru bicara dari komunikasi publik. Kenapa ini dilakukan adalah untuk mengatasi kejenuhan masyarakat.

Edukasi yang khusus diperuntukan kepada masyarakat adat dalam suatu program kegiatan yang dirancang secara tersendiri terasa masih kurang. Program edukasi terhadap masyarakat adat yang dilakukan oleh Pemerintah Kota Ambon, untuk pertama kalinya baru dilakukan bekerjasama dengan Fakultas Ilmu Sosial dan Ilmu Pemerintahan serta dengan Fakultas Kedokteran melalui program pengabdian masyarakat dalam penanggulangan Covid 19 berbasis komunitas. Mereka juga berkolaborasi dengan anggota DPRD kota Ambon yang daerah pemilihannya meliputi Negeri Laha, Desa Wayame dan Negeri Hukurila yang menjadi daerah sasaran program dimaksud.

Gusus tugas percepatan penanggulangan Covid 19 Provinsi Maluku melalui Dinas Kesehatan Pemerintah Provinsi Maluku telah melakukan tindakan awal dalam mendeteksi dan merespon dengan mengikutsertakan partisipasi seluruh sektor sesuai dengan Pedoman Kesiapsiagaan Menghadapi Coronavirus Disease (COVID-19). ${ }^{17}$ Standar Kewaspadaan dalam mentaati protocol Kesehatan seperti mengenakan APD, masker kaca mata pelindung, sarung tangan, etika ketika batuk dan menggunakan hand hygiene serta social distancing, perlu dipraktekan secara baik dan benar bagi semua pihak terutama tenaga sukarelawan. ${ }^{18}$

Meskipun demikian, menurut Ketua Ombudsman Perwakilan Maluku hal itu belumlah maksimal. Komisi Ombudsman Perwakilan Provinsi Maluku pernah memediasi dan memfasilitasi Dinas Kesehatan Provinsi Maluku untuk dapat berdiskusi dan mencari solusi bersama dengan beberapa Rumah Sakit dan Klinik Kesehatan di Maluku yang memungut biaya rapid test beragam antara $\mathrm{Rp} 600.000$ sampai Rp. 300.000 sementara telah dikeluarkan standar batas tertinggi biaya rapid test dari Kementerian Kesehatan (Kemenkes) sebesar Rp150.000, sesuai SE No. HK.02.02/I/2875/2020 mengenai batasan tarif tertinggi pemeriksaan rapid test antibody, standar biaya rapid test yang ditentukan oleh Pemerintah Pusat dan diberlakukan sama untuk semua daerah di Indonesia, dirasa memberatkan bagi institusi Kesehatan di Maluku yang berkarakteristik kepulauan yang memiliki potensi high cost. Sementara masyarakat disatu sisi berharap agar biaya rapid test dapat ditekan semurah mungkin. Sehingga akhirnya diambil kebijakan bahwa pemda Maluku harus memberikan subsidi.

Begitupun pelayanan kesehatan di beberapa fasilitas pelayanan kesehatan pemerintah daerah Maluku sempat dihentikan sementara, ketika dua orang dokter yang bekerja di Rumah Sakit Umum (RSU) dr. Haulusy terpapar Covid 19. Penutupan Rumah Sakit dan Puskesmas tersebut mendapat reaksi keras dari Komisi Ombudsman Perwakilan Provinsi Maluku. Menurut Hasan Slamat bahwa penutupan RSU dan Puskesmas melanggar hak atas pelayanan kesehatan bagi masyarakat, dengan demikian dapat diketahui bahwa pemenuhan hak atas informasi, edukasi dan pelayanan kesehatan kepada masyarakat adat telah dilakukan oleh Pemerintah Provinsi Maluku, namun belum terpenuhi secara maksimal.

\section{Kebijakan Publik Pemerintah Provinsi Maluku dalam Membangun Pola Relasi antara Pemerintah Daerah dan Masyarakat Adat sebagai Upaya Percepatan Penanggulangan Penyebaran Virus Covid 19 Di Tingkat Lokal}

17 Kemenkes, (2020). Pedoman Kesiapsiagaan Menghadapi Covid-19. Revisi ke-3, Jakarta: Kementerian Kesehatan RI

18 Asyary, A., \& Veruswati, M. (2020). Sunlight exposure increased Covid-19 recovery rates: A study in the central pandemic area of Indonesia. Science of The Total Environment, 729, 139016. DOI: https://doi.org/10.1016/j.scitotenv.2020.139016 h. 3

$$
\text { 154|SASI Vol. } 27 \text { No.2, April - Juni } 2021
$$


Kesehatan bagi masyarakat adat, menurut Corinne Lennox and Carolyn Stephens, ${ }^{19}$ bahwa masyarakat adat memahami konsep kesehatan secara menyeluruh bukan hanya diartikan sebagai penyakit saja namun terkait dengan kelemahan lainnya. Demikianpun tentang konsep Kesehatan masyarakat yaitu bahwa kesehatan adalah konsep yang terkait dengan komunitas bukan hanya individu.

Peran dan campur tangan pemerintah dalam melindungi masyarakat adat merupakan bentuk prinsip tanggung jawab negara. Demikianpun, pemerintah daerah mengambil bagian dalam mengurus dan melindungi masyarakat adat di daerah.

Berkaca pada tindakan pemerintah Canada terhadap masyarakat adatnya selama pandemic virus covid-19 dapat menjadi bahan dan model dalam pola relasi antara pemerintah daerah dan masyarakat adat dalam menjalin interaksi dinamis di tingkat local. Indigenous Services Canada (ISC) Minister Marc Miller ${ }^{20}$ menyatakan bahwa Pemerintah Canada melalui Menteri Indigenous Services Canada (ISC) Marc Miller telah mempersiapkan langkah startegis dalam membantu penduduk asli di Canada. Oleh karena itu, di saat pandemic Covid 19, pemerintah Canada dengan serius memperhatikan kerentanan yang tinggi pada penduduk aslinya.

Menurut PBB bahwa masyarakat adat secara historis menghadapi pengucilan sosial dan marginalisasi. Mereka secara tidak proporsional terwakili di antara orang miskin dan sangat miskin, tingkat akses mereka ke layanan kesehatan dan pendidikan yang memadai jauh di bawah rata-rata nasional, dan mereka sangat rentan terhadap konsekuensi degradasi lingkungan. ${ }^{21}$ Kenyataan ini membuat, Anne Nuorgam, menyerukan kepada semua negara di dunia agar memasukkan kebutuhan dan prioritas khusus masyarakat adat dalam menangani wabah global COVID-19.

Kebijakan publik pemerintah Provinsi Maluku dalam menjawab tantangan ini, dapat mengacu pada pendapat Tangkilisan, ${ }^{22}$ bahwa pemerintah dalam membuat dalam membuat kebijakan publik harus dapat memberdayakan secara strategis semua sumberdaya yang tersedia sebagai solusi atas permasalahan yang dihadapi masyarakat. Kebijakan publik hendaknya dilakukan secara kontinyu oleh pemerintah untuk mengintervensi kepentingan kelompok yang termarginal dalam masyarakat sehingga mereka dapat hidup sejahtera, dan menjadi unsur yang turut menentukan jalannya pembangunan. Berdasarkan konsep kebijakan publik maka pemerintah Provinsi Maluku harus terlebih dahulu memiliki kebijakan publik dalam membangun pola relasi antara Pemerintah Daerah dan masyarakat adat untuk menjalin interaksi dinamis di tingkat lokal. Kebijakan publik dimaksud harus dilakukan sesuai dengan kerangka kebijakan publik dengan lebih dahulu mengidentifikasi variabel-variabelnya. Dengan melakukan kajian yang teliti berbasis instrumen terukur akan diperoleh keakuratan informasi dimaksud. ${ }^{23}$ Menurut Valerisha dan Putra bahwa data yang transparan akan membantu masyarakat meningkatkan kewaspadaan sehingga upaya pencegahan potensi penularan dapat diminimalkan. ${ }^{24}$

19 Lennox, C., \& Stephens, C. (2013). Realizing the right to health for minorities and indigenous peoples. Minority Rights Group International. h.1

20 Stefanovich, O. (2020). No Indigenous community will be 'left behind' in COVID-19 response, says minister, https://www.cbc.ca/news/politics/stefanovich-federal-indigenous-covid19-support-1.5503079.

21 Assembly, U. G. (2007). United Nations declaration on the rights of indigenous peoples. UN Wash, 12, $1-18$.

22 Tangkilisan, H. N. S. (2003). Kebijakan publik yang membumi: konsep, strategi \& kasus. Yogyakarta: Lukman Offset \& Yayasan Pembaruan Administrasi Publik Indonesia, h. 1.

23 Rochmayati, S. (2019). Gambaran Pelaksanaan Joint Risk Assessment Kejadian Flu Burung Di Bali Tahun 2017. Journal of Public Health Research and Community Health Development, 3(1), 08-18. h. 8

24 Valerisha, A., \& Putra, M. A. (2020). Pandemi Global COVID-19 dan Problematika Negara-Bangsa: Transparansi Data Sebagai Vaksin Socio-digital?. Jurnal Ilmiah Hubungan Internasional, Edisi Khusus, 131-137. DOI: https://doi.org/10.26593/jihi.v0i0.3871.131-137, h. 185.

$$
\text { 155|S A S Vol. } 27 \text { No.2, April - Juni } 2021
$$


Apabila mengacu pada teori kebijakan publik Suharno, ${ }^{25}$ maka kerangka kebijakan publik harus memenuhi beberapa variabel berikut ini yaitu diantaranya adalah menentukan tujuannya, memilah prefensi nilai, menyiapkan sumber dayanya, mengetahui kemampuan aktor yang terlibat, kualitas aktor pembuat kebijakan sesuai kompetensinya dan memahami lingkungan sosial, ekonomi, politik, dan sebagainya dimana kebijakan tersebut akan diberlakukan, serta memiliki strategi jitu dalam meraih tujuan yang dikehendaki

Berdasarkan teori tersebut maka pemerintah Provinsi Maluku dalam membuat kerangka kerja kebijakan publik agar efektif dalam memenuhi hak masyarakat adat atas informasi, edukasi dan pelayanan kesehatan maka dapat menggunakan variabel dimaksud, yaitu:

a) Menentukan tujuannya. Sedapat mungkin tujuannya jangan terlampau kompleks. Tujuan kebijakan sebaiknya, dibuat sesederhana mungkin, sehingga mudah dicapai. Oleh karena itu, Pemerintah Provinsi Maluku perlu hanya menetapkan satu tujuan utama pencapaian kinerja kebijakan publik yaitu tujuannya adalah pemenuhan hak atas informasi, edukasi dan pelayanan kesehatan kepada masyarakat adat.

b) Memilah prefensi nilai. Kebijakan yang terdiri dari banyak variasi nilai akan sulit untuk dicapai. Oleh karena itu, pemerintah Provinsi Maluku perlu menetapkan cukup satu preferensi nilai yang menjadi sasaran pencapaian. Preferensi nilai tersebut adalah mencakup nilai-nilai dan preferensi masyarakat adat yang merupakan equilibrium yang dicapai dalam perjuangan mereka dalam mendapat hak atas informasi, edukasi dan pelayanan kesehatan. Terpenuhinya nilai dan preferensi hak atas informasi, edukasi dan pelayanan kesehatan pada masyarakat adat akan dapat memenuhi keinginan dan harapan mereka, mengingat hak-hak ini penting dimasa pendemik covid 19 bagi masyarakat adat

c) Menyiapkan sumber dayanya untuk mendukung kebijakan. Sumber daya, baik bersifat finansial, maupun material, ataupun infrastruktur lainnya perlu disiapan oleh pemerintah Provinsi Maluku. Kebijakan anggaran diprioritaskan kepada masyarakat adat, sehingga politik anggaran harus berpihak pada kepentingan masyarakat adat. Oleh karena itu, porsi anggaran harus lebih besar untuk dapat dialokasikan kepada kepentingan masyarakat adat dalam memenuhi hak atas informasi, edukasi dan pelayanan kesehatan secara lebih memadai, selain perlunya kesiapan material dan infrastruktur yang mendukung kearah itu.

d) Kemampuan aktor yang terlibat dalam pembuatan kebijakan. Semua aparat pemerintah daerah di Maluku harus dapat menjadi actor yang berperan dalam pembuatan kebijakan yang pro pada masyarakat adat, termasuk kepala daerah dan terlebih pimpinan OPD (Organisasi Perangkat Daerah). Pimpinan OPD pada level tertinggi dalam bidangnya harus menjadi leading sector terdepan dalam membantu masyarakat adat dalam memenuhi hak atas informasi, edukasi dan pelayanan kesehatan mereka. Pimpinan OPD harus menjadi actor penting dalam mengimplementasi kebijakan kepala daerah maupun kebijakan internal sector sesuai bidang tanggung jawabnya. Selain itu, elite pimpinan di daerah juga harus mampu bersinergi dengan actor-aktor lainnya di masyarakat adat dalam membuat kebijakan dimaksud maupun dalam mengimplementasikannya.

e) Kualitas aktor pembuat kebijakan sesuai kompetensinya. Standar kompetensinya ditentukan oleh tingkat Pendidikan sesuai bidangnya, pengalaman kerja dan integritas moralnya. Oleh karena itu, Gubernur, Bupati dan Walikota serta pimpinan OPD di provinsi Maluku sebagai pengambil keputusan dan kebijakan puncak di daerah Maluku harus memenuhi kompetensi yang tidak diragukan lagi kualitasnya. Apalagi mereka sendiri lebih banyak berasal dari masyarakat adat sehingga merekalah yang paling tahu kebutuhan dan kepentingan masyarakat adatnya selama

25 Suharno. (2010). Dasar-dasar Kebijakan Publik, Yogyakarta: UNY Press, h. 31 
pandemic covid-19 ini. Sudah mestinya mereka dapat melahirkan kebijakan yang berkualitas jika terkait dengan kepentingan masyarakat adat. Sungguh sangat memalukan bilamana selama kepemimpinannya di daerah ternyata dilakukan dengan cara-cara yang mengabaikan hak-hak dasar masyarakat adatnya sendiri.

f) Memahami lingkungan sosial, ekonomi, politik, dan sebagainya dimana kebijakan tersebut akan diberlakukan. Di Maluku masih memiliki tatanan nilai-nilai adat yang masih dipegang teguh oleh masyarakat adat. Ditengah gempuran modernisasi dan peradaban kekinian masyarakat adat masih cukup kokoh mempertahankan eksistensinya. Hal ini dapat menjadi kekuatan dan modal ketahanan masyarakat adat baik dalam hubungan social, kebutuhan dalam pemenuhan ekonomi maupun dalam dinamika politik local. Pemerintah Provinsi Maluku dalam mensinergikan kebijakan pemenuhan hak informasi, edukasi dan pelayanan kesehatan dapat menggunakan modal social yang masih dipegang teguh oleh masyarakat adat demi dapat memperkuat political will tersebut.

g) Memiliki strategi jitu dalam meraih tujuan yang dikehendaki. Mengimplementasikan suatu kebijakan dapat menggunakan stretegi yang bersifat top/down approach atau bottom approach, otoriter atau demokratis. Pemilihan bentuk strategi implementasi kebijakan pemerintah daerah Maluku yang memprioritaskan kepentingan masyarakat adat atas hak informasi, edukasi dan pelayanan kesehatan akan lebih bijak jika menggunakan strategi kebijakan bottomup approach. Kebijakan dimaksud dapat menumbuhkan tingkat partisipasi masyarakat adat karena masyarakat adat diberikan ruang dan kebebasan untuk dapat menentukan sendiri keputusan yang terbaik bagi kepentingan mereka selama dalam masa pandemic covid-19. Menurut Yance Arizona bahwa mereka perlu diberikan kemandirian dalam pengambilan keputusan (selfdetermination) dan menentukan sendiri pilihan-pilihan yang terbaik bagi komunitasnya (free prior and informed consent) harus dapat di hormati oleh pemerintah Provinsi Maluku. Hal ini menurut Yance Arizona adalah penting bagi sebagai bagian dari pendekatan pluralis yang memandang bahwa masyarakat adat sebagai keberagaman yang yang perlu terus dijaga dan dijamin hak-hak dasarnya. Oleh sebab itu, setiap pembanguan dalam masyarakat adat dan wilayah ulayatnya harus melibatkan pastisipasi aktif masyarakat adat. ${ }^{26}$

Pemerintah Provinsi Maluku dalam penangganan covid-19 telah diperkuat dengan peraturan Gubernur Maluku No. 39 Tahun 2020 Tentang Pedoman Pencegahan dan Pengendalian Corona Virus Disease 2019 (Covid-19) Di Provinsi Maluku, yang ditetapkan Pada Tanggal 04 Agustus 2020. Pergub ini dapat didjadikan landasan kebijakan publik dan dapat menjadi acuan bagi pengambil kebijakan untuk melindungi dan memenuhi hak-hak masyarakat adat di Daerah Maluku. Peraturan Gubernur ini bertujuan untuk memaksimalkan upaya pencegahan dan memutus mata rantai COVID-19 dengan mempertimbangkan konteks kewilayahan, sosial budaya dan kapasitas kesehatan di Provinsi Maluku (Pasal 3). Formulasi kebijakan dalam bentuk peraturan gubernur dimkasud perlu diimplementasikan lebih lanjut oleh pemangku kepentingan di daerah dengan kegiatan dan program yang "care event", kepada masyarakat adat dengan cara pengembangan pilihan dan menentukan alternatif kebijakan dalam menghadapi masalah isu pemenuhan hak-hak masyarakat adat atas informasi, edukasi dan pelayanan kesehatan. Untuk itu, pemahaman dan sensivitas terhadap kesadaran dan lingkungan strategik, antisipasi perilaku politik para stakeholders dalam formulasi kebijakan, serta dan system dan stratifikasi kebijakan, alternatif kebijakan yang dipilih harus dapat diarahkan sesuai model perumusan kerangka kerja kebijakan yang berorientasi pada tujuan pemenuhan hak atas informasi, edukasi dan pelayanan kesehatan masyarakat adat sebagaimana telah dijelaskan

26 Arizona, Y. (2016). Memahami Masyarakat Adat: Pendekatan Evolusionis versus Pluralis. makalah disampaikan dalam Focus Group Discussion (FGD) Perlindungan Kosntitusional Masyarakat Hukum Adat yang diselenggarakan oleh Pusat P4TIK Mahkamah Konstitusi di Jakarta

$$
\text { 157|SASI Vol. } 27 \text { No.2, April - Juni } 2021
$$


diatas, dengan demikian diharapkan tercipta kebijakan publik Pemerintah Provinsi Maluku dalam membangun pola relasi antara pemerintah daerah dan masyarakat adat sebagai upaya percepatan penanggulangan penyebaran virus covid 19 di tingkat lokal.

\section{PE N U T U P}

Pemenuhan hak atas informasi, edukasi dan pelayanan kesehatan kepada masyarakat adat di Maluku selama pandemic Covid-19 belum dilakukan secara maksimal oleh Pemerintah Provinsi Maluku. Pemerintah Provinsi Maluku juga belum optimal dalam membuat dan memiliki kebijakan publik yang lebih berpihak kepada kepentingan masyarakat adat sebagai bentuk tindakan perlindungan atas kerentanan masyarakat adat dari bahaya penyebaran virus covid-19. Namun demikian, keinginan untuk menuju kearah tersebut semakin terlihat. Pemerintah Provinsi Maluku perlu merumuskan formulasi kerangka kerja kebijakan publik yang berorientasi kepada tujuan yang hendak dicapai selama masa pandemic covid-19 dan memeriksa kecukupan sumberdaya yang tersedia baik dana, sumber daya manusia dan material serta infrastruktur yang mendukung pencapaian kinerja dalam pemenuhan hak atas informasi, edukasi dan pelayanan kesehatan kepada masyarakat adat di Maluku.

\section{DAFTAR PUSTAKA}

\section{Jurnal}

[1] Asyary, A., \& Veruswati, M. (2020). Sunlight exposure increased Covid-19 recovery rates: A study in the central pandemic area of Indonesia. Science of The Total Environment, 729, 139016. DOI: https://doi.org/10.1016/j.scitotenv.2020.139016.

[2] Djalante, Riyanti, et al. (2020). Review and analysis of current responses to COVID-19 in Indonesia: Period of January to March 2020. Progress in Disaster Science, 6(4), 1-9. DOI: https://doi.org/10.1016/j.pdisas.2020.100091.

[3] Elfi Quyumi, E., Alimansur, M. (2020). Upaya Pencegahan Dengan Kepatuhan Dalam Pencegahan Penularan Covid-19 Pada Relawan Covid. Journal of Public Health Research and Community Health Development (JPH RECODE) 4(1), 81-87. DOI: http://dx.doi.org/10.20473/jphrecode.v4i1.21792.

[4] Mona, N. (2020). Konsep isolasi dalam jaringan sosial untuk meminimalisasi efek contagious (kasus penyebaran virus corona di Indonesia). Jurnal Sosial Humaniora Terapan, 2(2), 117-125. DOI: https://doi.org/10.7454/jsht.v2i2.86.

[5] Rochmayati, S. (2019). Gambaran Pelaksanaan Joint Risk Assessment Kejadian Flu Burung Di Bali Tahun 2017. Journal of Public Health Research and Community Health Development, 3(1), 08-18

[6] Rosyada, A., Warassih, E., \& Herawati, R. (2018). Perlindungan Konstitusional terhadap Kesatuan Masyarakat Hukum Adat dalam Mewujudkan Keadilan Sosial. Kanun Jurnal Ilmu Hukum, 20(1), 1-22. DOI: https://doi.org/10.24815/kanun.v20i1.10021.

[7] Valerisha, A., \& Putra, M. A. (2020). Pandemi Global COVID-19 dan Problematika Negara-Bangsa: Transparansi Data Sebagai Vaksin Socio-digital?. Jurnal Ilmiah Hubungan Internasional, Edisi Khusus, 131-137. DOI: https://doi.org/10.26593/jihi.v0i0.3871.131-137.

[8] Wahidah, I., Athallah, R., Hartono, N. F. S., Rafqie, M. C. A., \& Septiadi, M. A. (2020). Pandemik COVID-19: Analisis Perencanaan Pemerintah dan Masyarakat dalam Berbagai Upaya Pencegahan. Jurnal Manajemen dan Organisasi, 11(3), 179-188.

[9] Wu, Y. C., Chen, C. S., \& Chan, Y. J. (2020). The outbreak of COVID-19: an overview. Journal of the Chinese medical association, 83(3), 217-220.

[10] Yuliana, Y. (2020). Corona virus diseases (Covid-19): Sebuah tinjauan literatur. Wellness And Healthy Magazine, 2(1), 187-192. 
[11]Zahrotunnimah, Z. (2020). Langkah taktis pemerintah daerah dalam pencegahan penyebaran virus Corona Covid-19 di Indonesia. SALAM: Jurnal Sosial Dan Budaya Syar$I, 7(3), 247-260$.

\section{Buku}

[12] Hutchinson, T. (2006). Researching and writing in law. Pyrmont-NSW-Sydney: Thomas Lawbook Co.

[13] Marzuki, P. M. (2017). Penelitian Hukum. Edisi Revisi, Jakarta: Kencana.

[14] Suharno. (2010). Dasar-dasar Kebijakan Publik, Yogyakarta: UNY Press.

[15] Tangkilisan, H. N. S. (2003). Kebijakan publik yang membumi: konsep, strategi \& kasus. Yogyakarta: Lukman Offset \& Yayasan Pembaruan Administrasi Publik Indonesia.

\section{Online/World Wide Web dan Lain-Lain}

[16] Arizona, Y. (2016). Memahami Masyarakat Adat: Pendekatan Evolusionis versus Pluralis. makalah disampaikan dalam Focus Group Discussion (FGD) Perlindungan Kosntitusional Masyarakat Hukum Adat yang diselenggarakan oleh Pusat P4TIK Mahkamah Konstitusi di Jakarta

[17] Assembly, U. G. (2007). United Nations declaration on the rights of indigenous peoples. UN Wash, 12, 1-18.

[18]Herin, F. P. (2020). Pelanggaran Warnai Hari Pertama PSBB, Pemkot Ambon Siapkan Penindakan, https://www.kompas.id/baca/nusantara/2020/06/22/pelanggaran-warnai-haripertama-psbb-pemkot-ambon-siapkan-penindakan/.

[19] Kemenkes, (2020). Pedoman Kesiapsiagaan Menghadapi Covid-19. Revisi ke-3, Jakarta: Kementerian Kesehatan RI.

[20]Lennox, C., \& Stephens, C. (2013). Realizing the right to health for minorities and indigenous peoples. Minority Rights Group International.

[21]Redaksiadmin. (2020). Gubernur Minta Warga Leihitu-Salahutu Bisa Masuk Kota. https://ameks.id/gubernur-minta-warga/.

[22] Satumaluku.id. (2020). Warga Hadang Ambulance dan Turunkan Paksa Jenazah Covid-19 di Tanjakan Batumerah Ambo. https://www.satumaluku.id/2020/06/26/warga-di-ambonhadang-ambulance-turunkan-paksa-jenazah-covid-kasus-577-di-maluku/.

[23] Stefanovich, O. (2020). No Indigenous community will be 'left behind' in COVID-19 response, says minister, https://www.cbc.ca/news/politics/stefanovich-federal-indigenouscovid19-support-1.5503079.

[24] Tribunnews.com. (2020). Sempat Ditolak Warga, Pemakaman Jenazah Pasien Positif Covid-19 di Ambon Penuh Isak Tangis Keluarga. https://www.tribunnews.com/corona/2020/05/04/sempat-ditolak-warga-pemakamanjenazah-pasien-positif-covid-19-di-ambon-penuh-isak-tangis-keluarga.

[25] Watloly, A. (2007). Filosofi Masyarakat Kepulauan, Disampaikan dalam Orasi Ilmiah pada Dies Natalis Universitas Pattimurta ke 44. 